\title{
Soil acidity characterization under different land use systems of Mizoram
}

BRAJENDRA, A. K. VISHWAKARMA AND MEGHNA SARMA

MEMBERS OF RESEARCH FORUM:

Corresponding author : BRAJENDRA, ICAR-Indian Institute of Rice Research, HYDERABAD (TELANGANA) INDIA

Co-authors :

A.K.VISHWAKARMA, ICAR-Indian Institute of Soil Science, BHOPAL (M.P.) INDIA

MEGHNA SARMA, ICAR Research Complex for North Eastern Hill Region, UMIAM (MEGHALAYA) INDIA

Received : 28.01.2016; Revised : 02.04.2016; Accepted : 28.04.2016

\section{Summary}

The $\mathrm{pH}$ of the soil is the most important characteristic in determining fertility of the soil. Soil reaction $(\mathrm{pH})$ affects various physical, chemical and biological properties of soils. Upland soils are usually characterized as highly erodible, leached in Mizoram and mostly soils are acidic to varying degree. Soils in their reaction varied from 4.79 to 6.14 in Kolasib district, 4.7 to 6.65 in Mammit district, 4.99 to 5.76 in Aizawl district, 4.51 to 5.71 in Serchip district, 4.59 to 6.49 in Lunglei district, 4.96 to 6.03 in Lawangtalai district, 5.94 to 7.24 in Saiha district and 4.99 to 5.92 in Champhai district. The organic matter content varied from 0.4 to 4.14 per cent with an average value of 2.22 .

Key words : Soil, Acidity, Land use

How to cite this article : Brajendra, Vishwakarma, A.K. and Sarma, Meghna (2016). Soil acidity characterization under different land use systems of Mizoram. Asian J. Soil Sci., 11 (1) : 110-114 : DOI : 10.15740/HAS/AJSS/11.1/110-114. 